\title{
Estrogenic Profile of the Svratka and Svitava Rivers in the Brno Area
}

\author{
Tomáš Nekvapil ${ }^{1}$, Ivana Borkovcová ${ }^{2}$, Miriam Smutná ${ }^{1}, Z_{\text {deňka Svobodová }}^{3}$ \\ ${ }^{1}$ Department of Biochemistry, Chemistry and Biophysics, ${ }^{2}$ Department of Milk and Dairy Products, \\ ${ }^{3}$ Department of Veterinary Public Health and Toxicology, Faculty of Veterinary Hygiene, \\ University of Veterinary and Pharmaceutical Sciences Brno, Czech Republic
}

Received May 19, 2008

Accepted October 1, 2008

\begin{abstract}
Estrogens are chemical compounds considered to be endocrine disruptors. They are thought to affect the endocrine system even at low concentrations found in water $\left(\mathrm{ng} \cdot \mathrm{l}^{-1}\right)$. The aim of this work was to determine estrogenic compound levels in the rivers in the Brno area. The concentration of $17 \beta$-estradiol, ethynylestradiol, estrone and diethylstilbestrol was estimated in the water samples collected in the Svratka and Svitava rivers.

Estrogens were isolated from the samples using solid-phase extraction with Oasis HLB cartridges and determined by means of reversed phase HPLC with UV detection. The detection limit of the method used was $6 \mathrm{ng} \cdot \mathrm{l}^{-1}$, repeatability expressed as RSD was $11 \%$, and recovery was $87-103 \%$. Estrogen values detected ranged in the interval of 6-209 $\mathrm{ng} \cdot \mathrm{l}^{-1}$, depending on the sampling site. After treatment in the sewage water treatment plant, the water displayed markedly lower levels of estrogenic compounds.

The results of the experiment demonstrate that HPLC-UV is a suitable method for determination of low concentrations of estrogens in water. The sewage water treatment plant reduces concentrations of estrogens but not sufficiently to prevent their estrogenic effect on fish.
\end{abstract}

Estrogens, HPLC, $17 \beta$-estradiol, environment, disruptors

Estrogens belong to the family of so-called steroid hormones. They are chemical compounds considered to be endocrine disruptors. Based on their incidence, they may be divided into natural estrogens and synthetic estrogens. Based on their origin, the division is into endogenous and exogenous ones (Holoubek and Čadová 2000). The most important natural hormones are, among others, $17 \beta$-estradiol and estrone; the most important synthetic hormones include ethynylestradiol. In aquatic ecosystems, their main source is domestic effluents, contaminated as a result of the wide-spread use of contraceptive pills and preparations for the treatment of hormonal disorders during the menopause.

Estrogens form from cholesterol in the reproductive organs and adrenal cortex of both sexes. In the body, they work as signal molecules which help the organism to react to the external environmental changes. Thanks to their lipophilic properties, they are capable of penetrating almost all types of cells but not all cells can display their action. They trigger this effect in a living organism by interacting with the nuclear receptor system. The consequent estrogen-receptor complex interacts with a nucleotide sequence called "estrogen response elements" (EREs), thus triggering DNA transcription. All estrogens (both environmental and natural) act by means of the receptor in a way that converts its inactive form into an active one.

Estrogens and other estrogen-like compounds released into the aquatic ecosystem interact with hormonal systems of wildlife and humans and cause female-specific response in males and juvenile organisms. This disruption of endocrine balance can result in an adverse impact on both sexes' fertility and behaviour (Comes et al. 2003). For instance, male fish turn female, unnatural reproduction processes take place; testicle and prostate gland cancer appear even at concentrations not exceeding $1 \mathrm{ng}$. The incidence of estrogenic compounds

Address for correspondence:

MVDr. Tomáš Nekvapil

Department of Biochemistry, Chemistry and Biophysics

University of Veterinary and Pharmaceutical Sciences Brno

Palackého 1-3, 61242 Brno, Czech Republic 
in the water ecosystem and their impact on the endocrine system both in humans and wildlife are receiving an ever-increasing attention.

Estrogens can be determined with immunological, biological or physically chemical techniques. Their determination is difficult because they are present in trace amounts $\left(\mathrm{ng} \cdot \mathrm{l}^{-1}\right)$ making it necessary to concentrate quite large volumes of aqueous solutions. The isolation is done with an extensive extraction, most frequently with the SPE method. Final determination is done using HPLC with UV/PDA, fluorescence or MS detection.

\section{Materials and Methods}

The method for determining water estrogenic compounds was chosen to be HPLC, after having isolated analytes with SPE. Basic method validation parameters, detection limit, reliability of the measurement, recovery and analyte stability were defined.

Samples were collected with a surface water sampler made by Optingservis from $30 \mathrm{~cm}$ deep at various Brno reservoir sites and the Svratka and Svitava rivers so that the estrogenic profile could be best captured. These sites were the Sokol bathing area at the Brno reservoir, the Svratka river outflow from the reservoir, a site just before its confluence with the Svitava river, the Svitava river point of entry in Obřany, a site before its confluence with the Svratka river and, finally, the inflow and outflow of the joint rivers to and from the sewage water treatment plant in Modřice. The samples were collected in the period from November 2007 to January 2008.

The samples were analyzed in at least duplicates within $24 \mathrm{~h}$ after collection.

Monitored analytes: 17ß-estradiol (E2), ethynylestradiol (EE), estrone (E1) and diethylstilbestrol (DES). The chromatogram of standard mixture is in Fig. 1.

Standard stock solutions of the $60 \mathrm{mg} \cdot 1^{-1}$ concentrations for $17 \beta$-estradiol and estrone, $180 \mathrm{mg} \cdot \mathrm{l}^{-1}$ for ethynylestradiol and $300 \mathrm{mg} \cdot \mathrm{l}^{-1}$ for diethylstilbestrol in methanol were prepared. Working solutions were prepared by diluting at a ten-fold, hundred-fold and thousand-fold ratio of mobile phases for HPLC immediately before use.

The most time-consuming step of the sample preparation was their filtering. The best results were acquired with combined filtration employing glass fibre filters and filter-paper using a Büchi/Sartorius vacuum manifold.

Analyte isolation from the water sample filtrate was done with solid phase extraction on Oasis HLB $3 \mathrm{cc} / 60 \mathrm{mg}$ and $6 \mathrm{cc} / 200 \mathrm{mg}$ (Waters, USA) SPE columns.

The columns were conditioned with diethyl ether, rinsed in methanol and deionised water. After loading 100 - $500 \mathrm{ml}$ of the filtered water sample, the column was washed with 5\% methanol in water and dried. Elution was carried out with $10 \%$ methanol in diethyl ether. The solvent was then evaporated from the eluate on a rotating vacuum evaporator; the residue was diluted with $1 \mathrm{ml}$ of mobile phase, filtered through a $0.45 \mu \mathrm{m}$ nylon filter and analyzed by HPLC.

The final determination was done using reversed-phase HPLC with the following equipment: liquid chromatograph Alliance 2695 with UV 2487 detector (Waters, USA), SunFire C18 chromatography column; $3.5 \mu \mathrm{m} ; 3.0 \times 150 \mathrm{~mm}$ (Waters, USA). The mobile phase was made of a mixture of acetonitrile and water at a $55: 45$ ratio, with a flow rate of $0.5 \mathrm{ml} \cdot \mathrm{min}^{-1}$. Column temperature was at $30^{\circ} \mathrm{C}$, injection volume $50 \mu 1$. UV detection was done at 205 and 220 $\mathrm{nm}$. The chromatogram of water sample is in Fig. 2. Its zoomed chromatogram is in Fig. 3.

Validation parameters of the method were defined as follows: limit of detection in the range of $1-6 \mathrm{ng} \cdot 1^{-1}$, repeatability established as RSD from ten parallel measurements was $11.1 \%$, recovery established by adding solutions of standards of known concentrations ranged in the interval of $87-103 \%$. The analytes were stable in the course of the analytical cycle (inter-day, $12 \mathrm{~h}$ ). When kept in cool and dark conditions, there were no changes even for several days (Salvador et al. 2007; Watabe et al. 2006; Wen et al. 2006).

\section{Results and Discussion}

Using the SPE and RP-HPLC methods, selected estrogenic compounds were determined as described above. In both rivers, a gradual increase of concentrations of estrogenic compounds can be detected throughout their courses in Brno. In the case of the Svratka river, we detected an increase especially in E2 (from 6.05 to $8.88 \mathrm{ng} \cdot 1^{-1}$ ), as well as in EE (5.90 to $9.90 \mathrm{ng} \cdot \mathrm{l}^{-1}$ ) and E1 (from 10 to $15.23 \mathrm{ng} \cdot 1^{-1}$ ). The Svitava river displayed the highest increase in E2 (from 19.87 to $25.20 \mathrm{ng} \cdot 1^{-1}$ ). It is also noteworthy that there was a relatively high increase in hormone concentrations in the inflow point at the sewage water treatment plant (E2 - $64.03 \mathrm{ng} \cdot l^{-1}, \mathrm{EE}-209.34 \mathrm{ng} \cdot \mathrm{l}^{-1}, \mathrm{E} 1-21.36 \mathrm{ng} \cdot \mathrm{l}^{-1}$ and DES $\left.113.25 \mathrm{ng} \cdot \mathrm{l}^{-1}\right)$. These levels were raised by mixing the river water with waste water coming into the plant. After receiving treatment, the water displayed significantly lower levels of estrogenic compounds $\left(\mathrm{E} 2-7.75 \mathrm{ng} \cdot \mathrm{l}^{-1}, \mathrm{EE}-8.20 \mathrm{ng} \cdot \mathrm{l}^{-1}, \mathrm{E} 1-2.84 \mathrm{ng} \cdot \mathrm{l}^{-1}\right.$ and DES $\left.16.59 \mathrm{ng} \cdot \mathrm{l}^{-1}\right)$. Lowering the levels of estrogenic compounds is quite effective, nevertheless, even lower concentrations, 


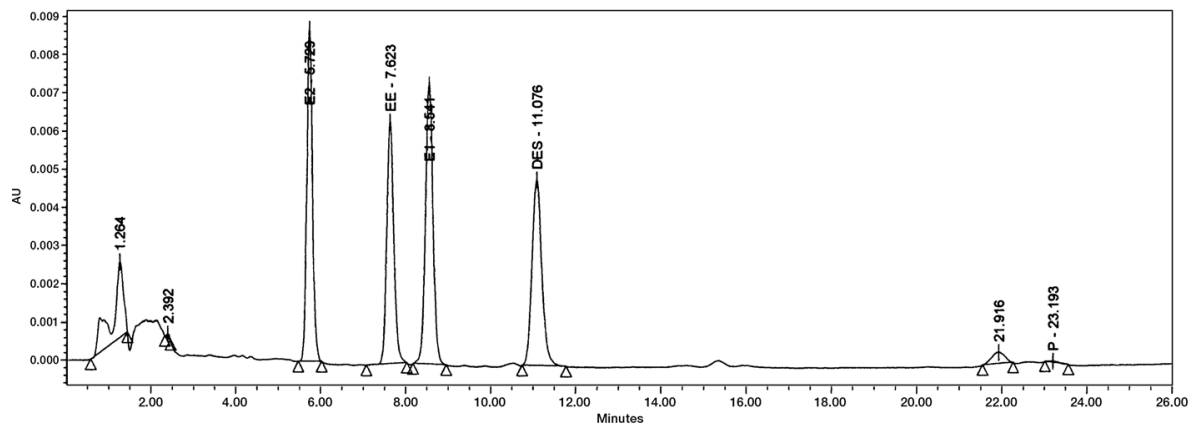

Fig. 1. Chromatogram of standard mixture of estrogens $17 \beta$-estradiol, ethynylestradiol, estrone diethylstilbestrol. Column SunFire C18; $3.5 \mu \mathrm{m} ; 3.0 \times 150 \mathrm{~mm}$. Mobil phase acetonitrile/water $55: 45$, flow $0.5 \mathrm{ml} \cdot \mathrm{min}^{-1}$. Column temperature $30^{\circ} \mathrm{C}$, the injection volume was $50 \mu$. Detection UV at $205 \mathrm{~nm}$.

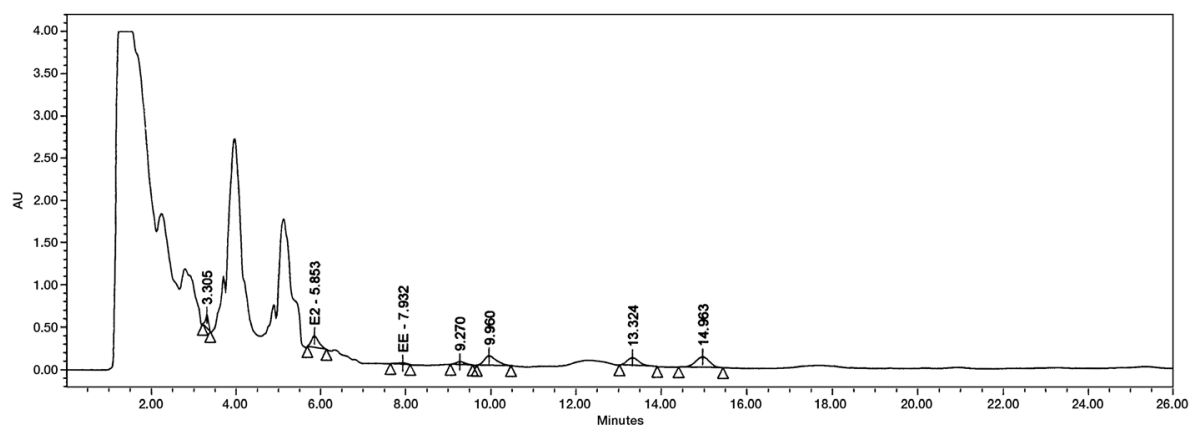

Fig 2. Chromatogram of the water sample 167

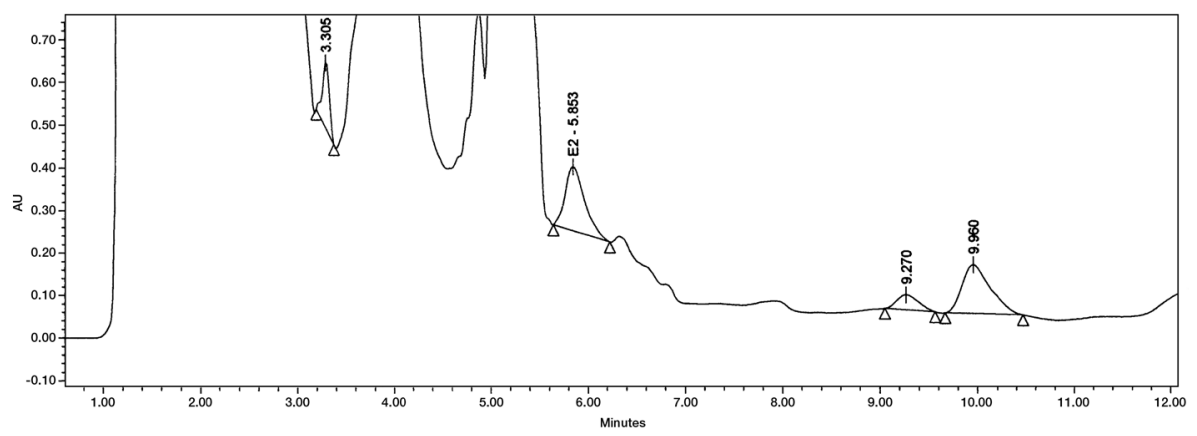

Fig. 3. Zoomed chromatogram of the water sample 
Table 1. Concentrations detected in the monitored analytes (in $\mathrm{ng} \cdot \mathrm{l}^{-1}$ )

\begin{tabular}{|l|c|c|c|c|}
\hline Description & E2-estradiol & EE-ethynylestradiol & E1-estrone & DES-diethylstilbestrol \\
\hline Sokol bathing area & 7.25 & 31.25 & 20.00 & 25.00 \\
\hline $\begin{array}{l}\text { Svratka outflow from } \\
\text { the reservoir }\end{array}$ & 6.05 & 5.90 & 10.00 & 23.60 \\
\hline $\begin{array}{l}\text { Svratka above the } \\
\text { confluence }\end{array}$ & 8.88 & 9.90 & 15.23 & 23.71 \\
\hline Svitava in Obřany & 19.87 & 25.00 & 13.98 & 21.25 \\
\hline $\begin{array}{l}\text { Svitava above the } \\
\text { confluence }\end{array}$ & 25.20 & 26.45 & 14.25 & 24.22 \\
\hline $\begin{array}{l}\text { Sewage water treatment } \\
\text { plant outflow }\end{array}$ & 7.75 & 8.20 & 2.84 & 16.59 \\
\hline $\begin{array}{l}\text { Sewage water treatment } \\
\text { plant inflow }\end{array}$ & 64.03 & 209.34 & 21.36 & 113.25 \\
\hline
\end{tabular}

if acting over a long period of time, can induce feminization or proliferation in fish and other river organisms.

Beck et al. (2005) have developed an analytical method for the determination of five naturally occurring estrogens (estradiol, estriol, estrone, genistein, daidzein) and synthetic hormone (ethynylestradiol). The procedure includes a solid phase extraction of 501 of water on Oasis HLB and a clean-up on silica. For the analytical determination of analytes HPLC coupled with MS/MS detection was used. Detection limits ranged from 0.02 to $1 \mathrm{ng} \cdot \mathrm{l}^{-1}$. The concentration of estrogens in coastal waters of the Baltic Sea was 0.1 to $17 \mathrm{ng} \cdot \mathrm{l}^{-1}$. Hu et al. (2005) established the LC/MS method for four estrogens (17 $\beta$-estradiol, estriol, estrone and ethynylestradiol in environmental water; detection limit $0.1-0.2 \mathrm{ng} \cdot \mathrm{l}^{-1}$. The method was used to detect residual estrogens in the Tonghui river, which receives water from a municipal sewage treatment plant in Beijing. E1 $\left(1.1 \mathrm{ng} \cdot l^{-1}\right)$ and E2 $\left(0.2 \mathrm{ng} \cdot \mathrm{l}^{-1}\right)$ were detected. Almeida et al. (2006) used stir bar sorption extraction and liquid de-sorption followed by high performance liquid chromatography with diode array detection for the simultaneous determination of nine steroid sex hormones (17 $\alpha$-estradiol, $17 \beta$-estradiol, $17 \alpha$-ethynylestradiol, diethylstilbestrol, mestranol, progesterone, 19-norethisterone and norgestrel) in water and urine matrices. Assays performed on $30 \mathrm{ml}$ water samples spiked at $10 \mu \mathrm{g} \cdot \mathrm{l}^{-1}$ levels, recoveries ranged from 11.1 to $100.2 \%$, precision was $2.1-17.1 \%$, limits of detection were $0.3-1.0 \mu \mathrm{g} \cdot \mathrm{l}^{-1}$. For the determination of analytes HPLC with linear gradient elution and detection at $200 \mathrm{~nm}$ was used. Gibson et al. (2007) used gas chromatography-mass spectrometry method for analysis of the samples of wastewaters and spring waters. Detection limits varied from 0.0005 to $1 \mathrm{ng} \cdot \mathrm{l}^{-1}$ in spring water and from 0.5 to $100 \mathrm{ng} \cdot l^{-1}$ in untreated wastewater. Concentration of the analytes in wastewater ranged from 0.018 to $22.4 \mu \mathrm{g} \cdot \mathrm{l}^{-1}$ and from 0.01 to $25 \mathrm{ng} \cdot \mathrm{l}^{-1}$ for spring water in metropolitan zone of Mexico City. Penalver et al. (2002) used HPLC with UV and electrochemical detection for determination of $\beta$-estradiol in samples from wastewater treatment plant in the Ebro river. The concentration was 1.9-2.2 $\mu \mathrm{g} \cdot \mathrm{l}^{-1}$. Rodriguez-Mozaz et al. (2004) used SPE, LC-MS for determination of estrone from surface and ground water, river water, water after each treatment step near Barcelona. The concentration reached $2-15 \mathrm{ng} \cdot \mathrm{l}^{-1}$ with LOD to $0.022 \mu \mathrm{g} \cdot \mathrm{l}^{-1}$

The results of this experiment demonstrate that HPLC-UV is a suitable method for determination of low concentrations of estrogens in water. The concentrations of estrogens in both rivers show their gradual increase during their flow through the city and their rise in the sewage water treatment plant. The plant reduces concentrations of estrogens but not sufficiently to prevent their estrogenic effect on fish. 


\section{Estrogenní profil řeky Svratky a Svitavy na území města Brna}

Estrogeny jsou chemické sloučeniny považované za endokrinní disruptory. Mohou narušovat endokrinní systém a to i v nízkých koncentracích, ve kterých se ve vodách nacházejí. Cílem této práce bylo stanovení estrogenů v řekách Svratka a Svitava na území města Brna. V odebraných vzorcích byly stanovovány koncentrace $17 \beta$-estradiolu, ethynylestradiolu, estronu a diethylstilbestrolu.

Estrogeny byly izolovány ze vzorků použitím SPE (Oasis HLB) a stanoveny pomocí HPLC-UV na reverzní fázi. Limit detekce byl $6 \mathrm{ng} \cdot \mathrm{l}^{-1}$, opakovatelnost metody vyjádřená jako RSD byla $11 \%$ a recovery se pohybovalo mezi 87 - $103 \%$. Naměrené hodnoty estrogenů se pohybovaly v intervalu 6-209 $\mathrm{ng} \cdot \mathrm{l}^{-1}$. Po pročištění v čistírně odpadních vod se koncentrace estrogenů výrazně snížila.

Výsledky experimentu ukazují možnost stanovení nízkých koncentrací estrogenů za použití HPLC-UV. Čistírna odpadních vod snižuje koncentrace estrogenů, ale ne dostatečně, aby došlo k zabránění jejich endokrinních účinků na ryby.

\section{Acknowledgement}

The study was supported by the project MSMT 2B06093.

\section{References}

Almeida C, Nogueira JMF 2006: Determination of steroid sex hormones in water and urine matrices by stir bar sorptive extraction and liquid chromatography with diode array detection. J Pharm Biomed Anal 41: 1303-1311

Beck IC, Bruhn R, Gandras J, Ruck W 2005: Liquid chromatography-tandem mass spectrometry analysis of estrogenic compounds in costal surface water of the Baltic Sea. J Chromatogr A 1090: 98-106

Comes RL, Scrimshaw MD, Lester JN 2003: Determination of endocrine disrupters in sewage treatment and receiving waters. Trends Analyt Chem 22: 697-707

Farre M, Kuster M, Brix R, Rubio F, Lopez de Alda M, Barcelo M 2007: Comparative study of an estradiol enzyme-linked immunosorbent assay kit, liquid chromatography-tandem mass spectrometry, and ultra performance liquid chromatography-quadrupole time of flight mass spectrometry for part-per-trillion analysis of estrogens in water samples. J Chromatogr A 1160: 166-173

Gibson R, Becerril-Bravo E, Silva-Castro V, Jimenez B 2007: Determination of acidic pharmaceuticals and potential endocrine disrupting compounds in wastewaters by selective elution and analysis by gas chromatography-mass spectrometry. J Chromatogr A 1169: 31-39

Holoubek I, Cadová L 2000: Estrogeny v životním prostředí (in Czech, Estrogens in the environment). Klin Onkol 13: 21-23

Hu J, Zhang H, Chang H 2005: Improved method for analyzing estrogens in water by liquid chromatographyelectrospray mass spectrometry. J Chromatogr A 1070: 221-224

Penalver A, Pocurull E, Borrul F, Marce RM 2002: Method based on solid-phase microextraction - highperformance liquid chromatography with UV and electrochemical detection to determine estrogenic compounds in water samples. J Chromatogr A: 964: 155-160

Rodriguez-Mozaz S, Lopez de Alda M, Barcelo M 2004: Monitoring of estrogens, pesticides and bisphenol A in natural waters and drinking water treatment plants by solid-phase extraction-liquid chromatography-mass spectrometry. J Chromatogr A 1045: 85-92

Salvador A, Moretton C, Priam A, Faure R 2007: On-line solid-phase extraction with on-support derivatization for high-sensitivity liquid chromatography tandem mass spectrometry of estrogens in ifluent/effluent of wastewater treatment plants. J Chromatogr A 1145: 102-109

Watabe Y, Kubo T, Nishikawa T, Fujita T, Kaya K, Hosoya K 2006: Fully automated liquid chromatography-mass spectrometry determination of 17ß- estradiol in river water. J Chromatogr A 1120: 252-259

Wen Y, Zhou B, Xu Y, Jin S, Feng Y 2006: Analysis of estrogens in environmental waters using polymer monolith in-polyether ether ketone tube solid-phase microextraction combined with high-performance liquid chromatography. J Chromatogr A 1133: 21-28 